\title{
Domestication: A Case Study of Red Jungle Fowl Coops Management by the Communities in Bengkulu
}

\author{
J. Setianto ${ }^{1,2}$, Sutriyono ${ }^{1}$, H. Prakoso ${ }^{1}$, dan B. Zain ${ }^{1}$ \\ ${ }^{1}$ Department of Animal Husbandry, Faculty of Agriculture, Universitas Bengkulu. \\ ${ }^{2}$ Graduate Program of Natural Resources and Environmental Management, Faculty of Agriculture, \\ Universitas Bengkulu. \\ Email: johansetianto@unib.ac.id
}

\begin{abstract}
Red junglefowl domestication has been carried out by communities in the region of Bengkulu Province. This research aimed to study the management of keeping red junglefowl and the offsprings and the coops. The research was carried out in Bengkulu Province. The sample of breeders was selected using snow-ball sampling method. The selected samples were recorded and used as the data and information sources. The data were collected by interviewing, questionnaires, and direct observation. The data obtained were processed, presented in the form of tables, drawings and analyzed descriptively. Based on research method, out of a total of 200 red junglefowl breeders and or the offsprings were chosen 50 (25\%) respondents from Bengkulu city, 50 (25\%) respondents from Seluma District, 50 (25\%) respondents from Central Bengkulu District and 50 (25\%) respondents from North Bengkulu District. The red junglefowl and the offsprings breeding is divided into keeping the hens, roosters and chicks. The hens were kept in the coop during the day and night (41\%), released during the day and night (22\%) and kept during the night in the coop and released during the day $(37 \%)$. In the same way, in sequence, the breeding of roosters was $71 \%, 12.5 \%$ and $16.5 \%$, while the breeding of chicks was $37 \%, 18 \%$ and $45 \% .31 \%$ respondents provided quarantine coop, while $69 \%$ respondents did not. $75 \%$ provided hens coop and $25 \%$ did not, $61 \%$ provided roosters coop and $39 \%$ did not. Finally, the respondents who provided chicks coop were $40.5 \%$ and $59.5 \%$ did not. The breeding management has not been done intensively, some respondents have completed coops system, but not yet meet the criteria of good coop.
\end{abstract}

Keywords: Domestication, red junglefowl, coops

\section{INTRODUCTION}

Red junglefowl is one of the germplasm animals that has significance for the people in Bengkulu. Domestication of red junglefowl has been done by the communities and spread in various areas in Bengkulu. Sulandari and Zein (2009) suggested that red junglefowl is the ancestor of local chicken that are maintained by the community at this time. Further Sulandari et al. (2008) said that Indonesian local chicken is in one clade with red junglefowl and red junglefowl is spread in Sumatra.

Communities in Bengkulu have long utilized red junglefowl. Red junglefowl married to chicken (Setianto, 2009a; Setianto, 2009b; Setianto, et al, 2009). From the crossbreeding got descendants which are named chicken burgo. Chicken burgo is preserved by the communities in Bengkulu (Setianto and Warnoto, 2010 and Setianto,
2013). This makes red junglefowl as a vital asset for acquiring new species (Setianto, et al, 2013; Setianto et al. 2015b; Setianto et al. 2014; Setianto et al. 2017b; Sutriyono et al., 2016; Widodo et al, 2014).

A lot of research on red junglefowl has been conducted, but the research on the domestication of red junglefowl by the community is still small. The research on the relationship between red junglefowl as ancestors of currently-kept chickens with genetic characteristics (Azmi, et al., 2000; Dorji et al., 2012; Moiseyeva et al., 2003; Sulandari et al., 2008). A research on population, behavior and habitat (Arshad and Zakaria, 2009; Javed and Rahmani, 2000; Subhani et al., 2010). Meanwhile, the study of the domestication of red junglefowl conducted by a community has not been done. Therefore, there is not much information available about various aspects of domestication by the community. 
From those various studies above, basic information on how to maintain and manage red junglefowl coop and the offspring by communities has not obtained yet. This study aimed to assess the keeping of red junglefowl and the offspring and the management of the coops. The results of the research will be used for the development of red junglefowl in the community.

\section{RESEARCH METHODS}

The study was conducted for 8 months, in Bengkulu city, Seluma District, Central Bengkulu and North Bengkulu District. The selection of research sites was determined purposively with the consideration that there were breeders who domesticated red junglefowl.

The sample or the respondents were the breeders who domesticated red junglefowl in the areas mentioned above. Selection of respondents was done by using Snow Ball sampling method. This method was done because the existence of breeders who domesticated red junglefowl has not been known for certain address. In the first stage, sampling was done by finding a breeder who domesticated red junglefowl. The next stage of sampling was done in a chain, starting from the first respondent, then the respondent was asked to provide information about other respondents who also breed red junglefowl. The next stage was done through the same process, so the number of respondents increased. In this study obtained 200 respondents, the breeders of red junglefowl and their offspring.

The data taken and collected in this research are primary and secondary data. Primary data were obtained directly from red junglefowl selected as a sample by using a combination of dept-interview and questionnaires. Primary data were also obtained through observation and direct measurement in the field. Secondary data were obtained from the results of previous studies, obtained from agencies or institutions that are closely related to research on wild chickens.
The data collected includes breeding, coop systems and the equipments. The data obtained were analyzed descriptively and presented in the form of tables and drawings.

\section{RESULTS AND DISCUSSION}

\section{Location and area of research}

The study sites were chosen to represent the central areas of Bengkulu (Bengkulu City and Central Bengkulu District), South (Seluma District) and North (North Bengkulu). The location and area of each city and district vary from the smallest $151,70 \mathrm{~km} 2$ and the widest area of 4,324.60 $\mathrm{km} 2$. Details of location and total area can be seen in table 1 below:

Table 1. Research Sites and total area in 3 districts and 1 city

\begin{tabular}{rlc}
\hline No & \multicolumn{1}{c}{ District/City } & Area (km2) \\
\hline 1 & North Bengkulu District & $4.324,60$ \\
2 & Seluma District & $2.400,44$ \\
3 & Central Bengkulu & $1.223,94$ \\
& District & 151,70 \\
4 & Bengkulu City &
\end{tabular}

Source:http://informasipedia.com/wilayahindonesia/daftar-luas-kabupaten-kota-diindonesia/794-daftar-luas-kabupatenkota-di-provinsi-bengkulu.html

Furthermore, the map of the study sites where respondents are domiciled can be seen in Figure 1 below:

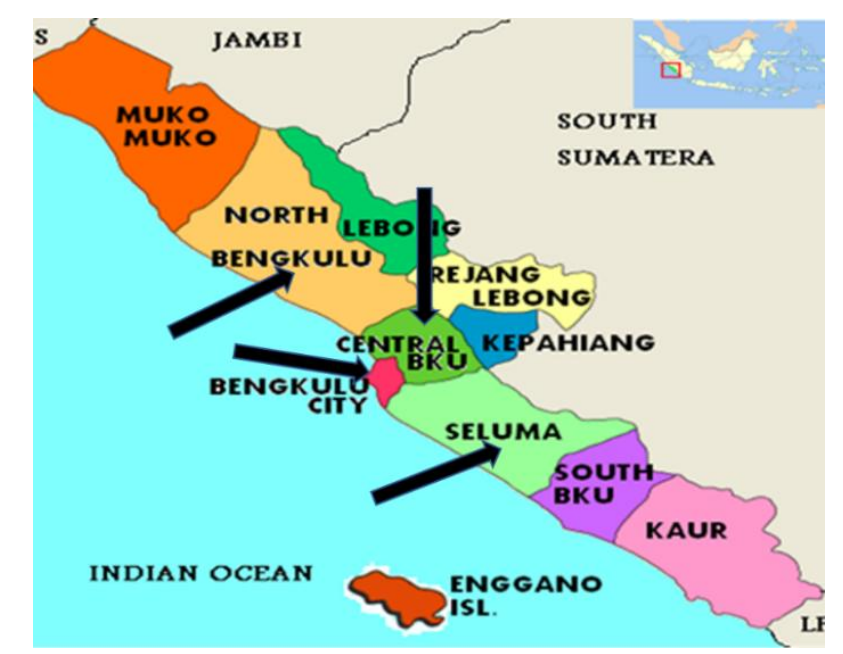

Figure 1. Map of Bengkulu Province (arrow indicates the location of the research) 


\section{Chicken keeping management}

From the results of the research can be seen that the respondents did not keep their red junglefowl intensively. Respondents kept their red junglefowl divided into keeping hens, roosters and chicks. In table 2 it can be seen how the respondents keep the red junglefowl and the offsprings:

Table 2. Chicken keeping management by the respondents

\begin{tabular}{|c|c|c|c|}
\hline \multirow{2}{*}{ No } & \multirow{2}{*}{ Variable } & \multicolumn{2}{|c|}{ Respondents } \\
\hline & & Person & $(\%)$ \\
\hline \multirow[t]{5}{*}{1} & Keeping Hens & & \\
\hline & $\begin{array}{l}\text { a. Kept during the day } \\
\text { and night }\end{array}$ & 82 & 41 \\
\hline & $\begin{array}{l}\text { b. Released during the } \\
\text { day and night }\end{array}$ & 44 & 22 \\
\hline & $\begin{array}{l}\text { c. Kept at night and } \\
\text { released during the day }\end{array}$ & 74 & 37 \\
\hline & Total & 200 & 100 \\
\hline \multirow[t]{5}{*}{2} & Keeping Roosters & & \\
\hline & $\begin{array}{l}\text { a. Kept during the day } \\
\text { and night }\end{array}$ & 142 & 71 \\
\hline & $\begin{array}{l}\text { b. Released during the } \\
\text { day and night }\end{array}$ & 25 & 12,5 \\
\hline & $\begin{array}{l}\text { c. Kept at night and } \\
\text { released during the day }\end{array}$ & 33 & 16,5 \\
\hline & Total & 200 & 100 \\
\hline \multirow[t]{5}{*}{3} & Keeping Chicks & & \\
\hline & $\begin{array}{l}\text { a. Kept during the day } \\
\text { and night }\end{array}$ & 74 & 37 \\
\hline & $\begin{array}{l}\text { b. Released during the } \\
\text { day and night }\end{array}$ & 36 & 18 \\
\hline & $\begin{array}{l}\text { c. Kept at night and } \\
\text { released during the day }\end{array}$ & 90 & 45 \\
\hline & Total & 200 & 100 \\
\hline
\end{tabular}

From table 2 above, it can be seen that not all of the respondents keep the chicken during the day and night. There were some respondents who took off the chickens during the day and night and there were the respondents who kept the chicken at night and then released during the day. The keeping management of hens, roosters and chicks remains a combination of keeping in the coop and releasing. The hens were kept up $41 \%$ of day and night, $22 \%$ was released during the day and night and $37 \%$ was kept at night and released during the day. The roosters were kept during the day and night by $71 \%, 12.5 \%$ was released during the day and night and $16.5 \%$ was kept at night and released daylight. The respondents kept their chicks during the day and night as much as $37 \%$, released during the day and night $(18 \%)$, while being kept at night and released in daylight as much as $45 \%$. From these data, interesting to be studied, the percentage of respondents who keep their roosters during the day and night was greater than hens and chicks. This is closely related to the function of a rooster as an ornamental chicken and decoy chicken with a relatively expensive price. Thus, keeping the chicken at night and day is one way for the chicken security from various threats of predators and theft. Not much different with the research result found by Sutriyono et al. (2017) on the way of keeping red forest birds in the coastal area of North Bengkulu. The keeping of red junglefowl by day and night $(52.17 \%)$, kept at night and released during the day (19.57\%), left to perch $(19.57 \%)$ and the combination of these methods (8.7\%). Meanwhile, Lopez, et al (2014) found that the majority of local chicken of breeders in Palawan, Philippines (64.8\%) was left free without provided coops, $26.8 \%$ providing coops combined with release. Only $7.4 \%$ of the respondents provided coops throughout the day. In line with N'Goran et al. (2016) pointed out that of 110 breeders, $54.55 \%$ of them has simple coops that do not meet building norms. In addition, there were $6.35 \%$ of the respondents who used the coop in the form of a cage that is only used at night and released during the day.

\section{Coops management}

Coops are important means of raising livestock, including chickens. Coops are needed by animals for shelter, rest, nesting containers, nursery, and so on. By way of keeping chickens as discussed above, then did the respondents provide a coop for the red junglefowl? In figure 2. below can be seen the availability of coops for the red junglefowl. 


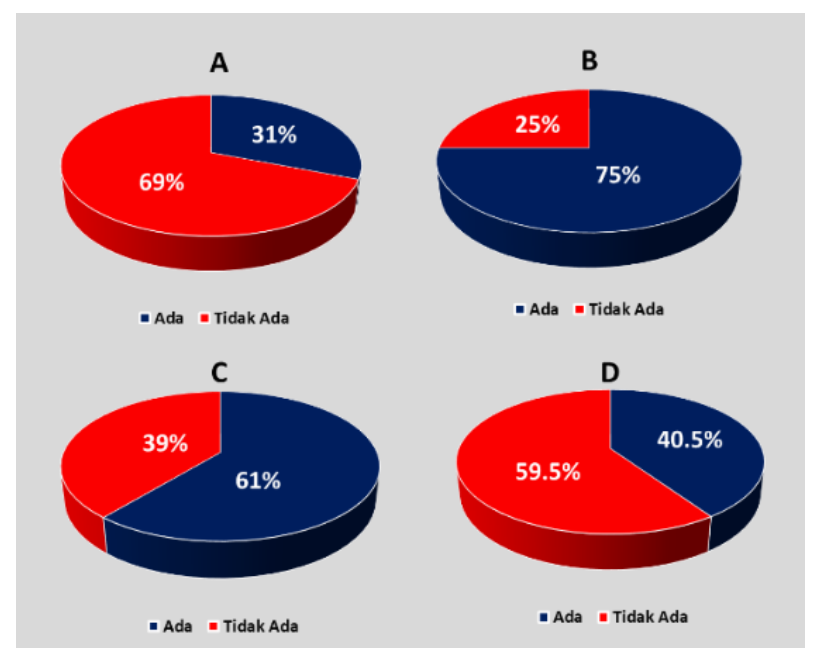

Figure 2. The Availability of Coops. (A) Quarantine Coops, (B) Hens Coop, (C) Rooster Coop (D) Chicks Coop.

The coops owned by the respondents vary greatly and almost every respondent had a different and very simple coop. Most coops for roosters were in the form of perch next to the respondent's house. In Figure 3 below can be seen various coops owned by the respondents.

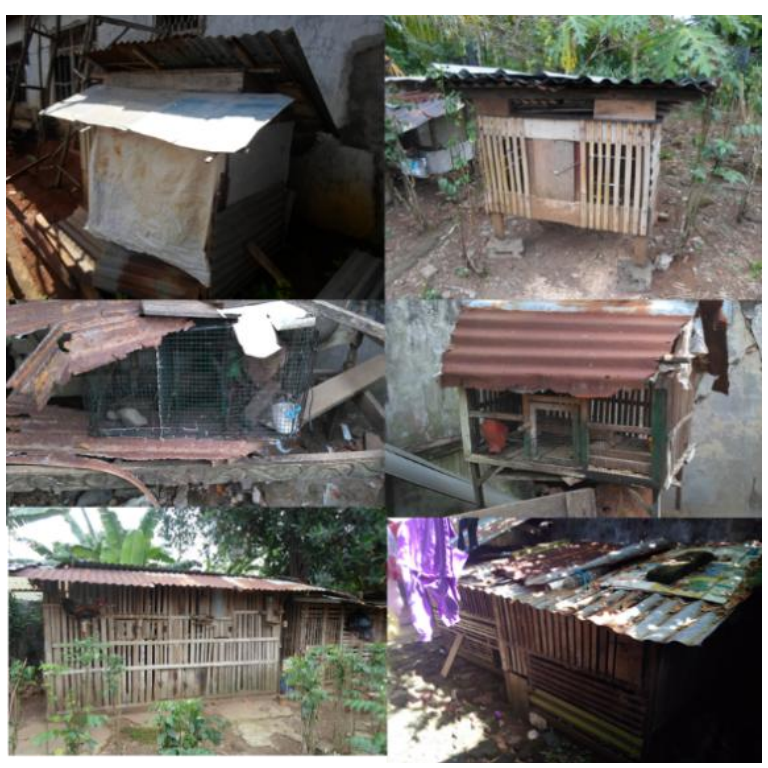

A

Figure 3. Coops for Red Junglefowl owned by the respondents. Common Coops (A), Rooster coops (B), Hens Coops (C), and Chicks Coops (D)

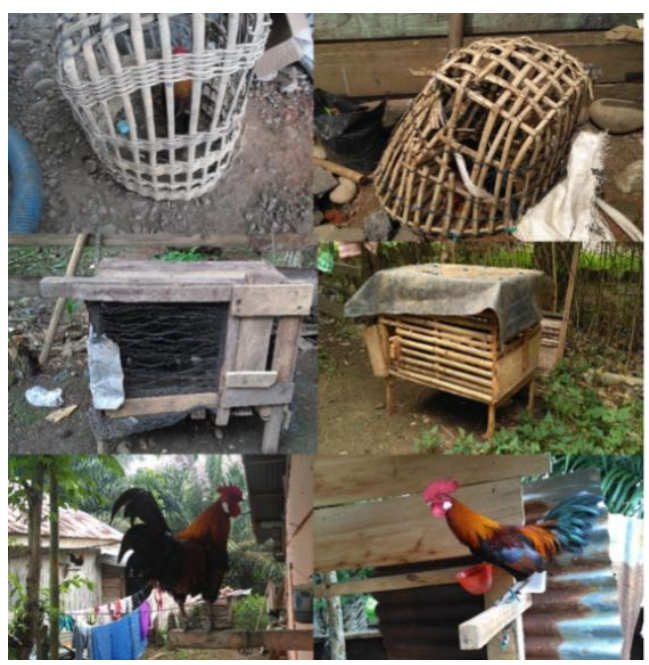

B

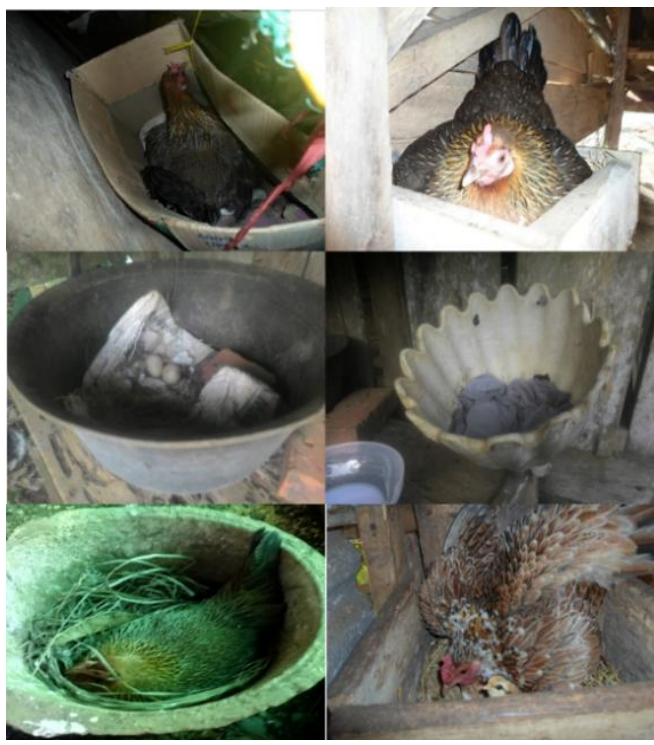

C

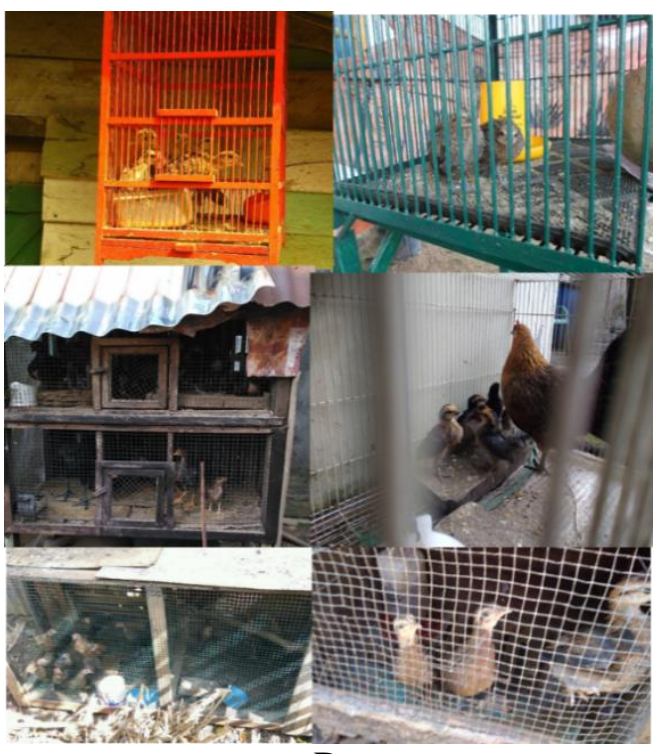

D 
The coops are grouped into special quarantine, hens, roosters and chicks' coops. In figure 2 above, it appears that more respondents provided a hen coop (75\%) compared with the other coops provision. Consecutively based on the provision of coops were (61\%) roosters coops, (40\%) chicks coops and $31 \%$ quarantine coops. Quarantine coops were the least owned by respondents. This is because the quarantine coop is only used for the hunted red junglefowl. As it is found that the origin of domesticated red-junglefowl is derived from hunting in nature (Setianto et al., 2015a; Setianto et al, 2016; Setianto et al, 2017b). Meanwhile, Ahlers et al (2009) suggested that local chicken farming uses low inputs. Coops are provided for chickens only at night, while daylight is released for feed. Other research results proposed N'Goran, et al, (2016) that $39.1 \%$ of the respondents who did not have a coop, so the chickens were allowed to sit everywhere.

Figure 3A shows the various varieties of coops owned by the respondents, including a sealed quarantine coop. While in Figure 3B shows images of coops, coops and perch are commonly used for roosters. From figure $3 \mathrm{C}$, it can be seen where the hen laying eggs that consist of various variations by utilizing the existing raw materials which are easily found in the environment of respondents. The shape and kind of coop for chicks owned by respondents are also very varied, as shown in figure 3D.

In addition to various forms of coops are very varied, the coops are equipped with feed and drink equipment. Feeding and drinking equipment is also very simple by utilizing what is available in the respondent's environment. In the following table 3 can be seen the equipments for feeding and drinking as well as the materials.

Table 3. Equipments and the materials of feeding and drinking containers owned by the respondents.

\begin{tabular}{|c|c|c|c|c|c|c|c|c|c|}
\hline \multirow[t]{2}{*}{ No } & \multirow[t]{2}{*}{ Variable } & \multicolumn{2}{|c|}{ Hens Coop } & \multicolumn{2}{|c|}{$\begin{array}{l}\text { Roosters } \\
\text { Coop }\end{array}$} & \multicolumn{2}{|c|}{ Chicks Coop } & \multicolumn{2}{|c|}{$\begin{array}{l}\text { Quarantine } \\
\text { Coop }\end{array}$} \\
\hline & & Person & $(\%)$ & Person & $(\%)$ & Person & $(\%)$ & Person & $(\%)$ \\
\hline \multirow[t]{11}{*}{1} & Feeding Containers & & & & & & & & \\
\hline & Bamboo & 1 & 0.5 & 0 & 0 & 2 & 1 & 0 & 0 \\
\hline & Fiber & 0 & 0 & 0 & 0 & 0 & 0 & 2 & 1 \\
\hline & Plastic Container & 70 & 35 & 104 & 52 & 51 & 25.5 & 40 & 20 \\
\hline & Shell & 37 & 18.5 & 36 & 18 & 49 & 24.5 & 24 & 12 \\
\hline & Wood & 0 & 0 & 5 & 2.5 & 4 & 2 & 2 & 1 \\
\hline & Board Box & 19 & 9.5 & 29 & 14.5 & 22 & 11 & 6 & 3 \\
\hline & Plastic Bottle & 4 & 2 & 3 & 1.5 & 2 & 1 & 1 & 0.5 \\
\hline & $\begin{array}{l}\text { Board Box and Plastic } \\
\text { Bottle }\end{array}$ & 1 & 0.5 & 0 & 0 & 0 & 0 & 0 & 0 \\
\hline & None & 68 & 34 & 23 & 11.5 & 75 & 37.5 & 125 & 62.5 \\
\hline & Total & 200 & 100 & 200 & 100 & 200 & 100 & 200 & 100 \\
\hline \multirow[t]{9}{*}{2} & Drinking Containers & & & & & & & & \\
\hline & Bamboo & 0 & 0 & 0 & 0 & 1 & 0.5 & 1 & 0.5 \\
\hline & Fiber & 0 & 0 & 0 & 0 & 0 & 0 & 1 & 0.5 \\
\hline & Plasctic Container & 70 & 35 & 118 & 59 & 72 & 36 & 50 & 25 \\
\hline & Shell & 37 & 18.5 & 35 & 17.5 & 3 & 1.5 & 17 & 8.5 \\
\hline & Board Box & 16 & 8 & 5 & 2.5 & 6 & 3 & 4 & 2 \\
\hline & Plastic Bottle & 8 & 4 & 12 & 6 & 4 & 2 & 1 & 0.5 \\
\hline & None & 69 & 34.5 & 30 & 15 & 114 & 57 & 126 & 63 \\
\hline & Total & 200 & 100 & 200 & 100 & 200 & 100 & 200 & 100 \\
\hline
\end{tabular}


From table 3 above, it can be seen from the main chicken coop or hens coop, the rooster, the chicks and the quarantine coop, the feed is dominated from plastics and shell containers. For the hen coop, the feed in the form of plastic containers as much as $35 \%$, shell as much as $18.5 \%$. For the rooster coop, plastics as much as $52 \%$ and shell as much as $18 \%$. On the same criteria in chicks and quarantine coop respectively are as much as $25,5 \%$ and $20 \%$ made of plastics, $24,5 \%$ and $12 \%$ made of shell. Interesting to study, there were still many coops without feeding containers. Most of the respondents did not provide feeding containers at the quarantine coop as much as $62,5 \%$, followed by chicks $(37,5 \%)$, hens $(34 \%)$ and roosters $(11,5 \%)$. It is closely related to the way of care that let the chickens release and find their own feed or fed simultaneously on the yard.

Not different from the feeding containers, where the drink is also dominated plastics and shell. Thirty five $(35 \%)$ drinking container of coop is made of plastics and $18.5 \%$ made of shell. $59 \%$ is made of plastics and $17.5 \%$ is made of shell for rooster coops. Meanwhile, coop for chicks is only dominated with plastic drinking containers as much as $36 \%$. Twenty five $(25 \%)$ made of plastics and $8.5 \%$ made of shell for quarantine coop. In terms of the provision of drinking containers, many respondents who also did not provide a drinking container. Almost the same as feeding containers, most of the quarantine coops $(63 \%)$ were not provided with the drinking containers, followed by chicks $(57 \%)$, hens $(34.5 \%)$ and roosters $(15 \%)$.

\section{CONCLUSION}

The keeping of domestically-red junglefowl still used an extensive way by releasing. Coops and feeding as well as drinking containers were not all available. The management of keeping chicken and coops is still very simple.

\section{ACKNOWLEDGMENT}

This research is a part of research of applied research scheme of higher education funded by DIPA Ministry of Research, Technology, and Higher Education. Therefore, the research team would like to thank the Directorate of Research and Community Service, Directorate General for Research and Development, Ministry of Research, Technology and Higher Education. The research was conducted based on the Letter of Agreement Number: 025/E3/2017 and Number: 990/UN30.15/LT/2017. Thanks also to the Institute of Research and Community Service (LPPM) University of Bengkulu.

\section{REFERENCES}

Ahlers, C., R. G. Alders, B. Bagnol, A. B. Cambaza, M. Harun, R. Mgomezulu, H. Msami, R. Pym, P. Wegener, E. Wethli, and M. Young. 2009. Improving village chicken production: a manual for field workers and trainers. Canberra, ACIAR. ISBN: 9781921531576

Arshad, M. I. dan M. Zakaria. 2009. Roosting habits of red jungle fowl in orchard area. Pak. J. Life Soc. Sci. 7(1) :86-89.

Mohd-Azmi, M. L., A. S. Ali, and W. K. Kheng. 2000. DNA fingerprinting of red jungle fowl, village chicken and broilers. Asian Aust. J. Anim. Sci. 13(8): 1040-1043.

Dorji, N., M. Duangjinda and Y. Phasuk. 2012. Genetic characterization of Bhutanese native chickens based on an analysis of Red Junglefowl (Gallus gallus gallus and Gallus gallus spadecieus), domestic Southeast Asian and commercial chicken lines (Gallus gallus domesticus). Genetics and Molecular Biology. 35(3) 603609. 
Javed, S. and A. R. Rahmani. 2000. Flocking and habitat use pattern of the Red Junglefowl Gallus gallus in Dudwa National Park, India. Tropical Ecology. 41(1): 11-16

Lopez Jr, R. V., A. L. Lambio, R. S. Vega, and A. P. O. De Guia. 2014. Management practices of native chicken (Gallus gallus domesticus Linn.) production in Palawan, Philippines. Philippine Journal of Veterinary and Animal Sciences. 40 (2): 109-120.

Moiseyeva, I. G., M. N. Romanov., A.A. Nikiforov, A. A. Sevastyanova and S.K. Semyenova. 2003. Evolutionary relationships of Red Jungle Fowl and chicken breeds. Genet. Sel. Evol. 35 (2003) 403-423.

N'Goran, K. E., N. E. Loukou, D. N. Dago, D. Ouattara, M. Sidibé, and A. F. Vanga. 2016. Characteristics of village chicken production in farming system in Côte d'Ivoire: case of Korhogo area. International Journal of Environmental \& Agriculture Research (IJOEAR). 2(1): 78 -85

Setianto, J., 2009 . Ayam Burgo : Ayam Buras Bengkulu. PT Penerbit IPB Press, Bogor.

Setianto, J., 2009 ${ }^{\mathrm{b}}$. Increasing the egg weight of burgo chicken offspring through cross-mating between burgo chicken with native chicken. Proceeding The $1^{\text {st }}$ International Seminar on Animal Industri "Sustainable Animal Production for Food Security and Safety. IPB Bogor. I : 262 -264.

Setianto, J. 2013. Potensi dan strategi pengembangan ayam burgo. Prosiding Seminar Nasional Peternakan: Potensi Sumber Daya Ternak Lokal untuk Membangun Kemandirian Pangan Hewani dan Kesejahteraan Masyarakat. Fakultas Peternakan, Universitas Andalas.
Padang. 20 November 2013. I: 15 20.

Setianto, J. dan Warnoto. 2010. Performa Reproduksi dan Produksi Ayam Burgo Betina. Penerbit UNIB PRESS, Bengkulu.

Setianto, J., Warnoto and Nurmeiliasari. 2009. The characteristic of egg production and reproduction of crossmating offspring between burgo chicken with native chicken. Proceeding International Seminar "The Role and Application of Biotechnology on Livestock Reproduction and Products" Bukittinggi, West Sumatra, I : 16 - 23.

Setianto, J., H. Prakoso dan Sutriyono. 2013. Dinamika populasi ayam burgo dan strategi pengembangannya di Bengkulu. Laporan Penelitian. Fakultas Pertanian Universitas Bengkulu.

Setianto, J., H. Prakoso, dan Sutriyono. 2014. Kajian domestikasi ayam hutan merah berbasis masyarakat serta strategi pengembangannya di Bengkulu. Laporan Penelitian Tahun 2014. Universitas Bengkulu, Bengkulu.

Setianto, J, Prakoso H, dan Sutriyono. 2015 . Performa produksi dan reproduksi ayam burgo pada peternakan rakyat di Kota Bengkulu. Prosiding Seminar Nasional Unggas Lokal V: "Peran Unggas Lokal dalam Menunjang Industri Perunggasan di Indonesia". Masyarakat Perunggasan Indonesia bekerjasama dengan Fakultas Peternakan dan Pertanian, Universitas Diponegoro. Semarang. 18 - 19 November 2015. I: 192: 201.

Setianto, J., H. Prakoso, Sutriyono. 2015 Domestikasi ayam hutan merah: Studi kasus penangkapan ayam hutan merah oleh masyarakat di Bengkulu Utara. Prosiding Seminar Nasional Masyarakat Biodiversitas Indonesia. 
Kerjasama Masyarakat Biodiversitas Indonesia, Universitas Indonesia dan Universitas Sebelas Maret. Depok, Bogor, 20 Desember 2014. 1 (2): 207 -212 .

Setianto, J., Sutriyono, H. Prakoso, B. Zain. 2016. Identifikasi asal-usul ayam hutan merah yang dipelihara mayarakat di Kabupaten Seluma. Jurnal Sain Peternakan Indonesia (JSPI). 11 (2): 141 - 152.

Setianto, J., Sutriyono, H. Prakoso, B. Zain. $2017^{\mathrm{a}}$. Red jungle fowl development scenarios for poultry farmers in Bengkulu coastal communities. Proceeding International Seminar and Expo: Sustainable Utilization of Coastal Resources in Tropical Zone. University of Bengkulu. $19-20$ October 2016. I : 407 - 413

Setianto, J., B. Zain, Sutriyono, H. Prakoso. $2017^{\mathrm{b}}$. Domestication of red jungle fowl: A case study of the red jungle fowl chicks procurement by the communities in Central Bengkulu, Indonesia. Biodiversitas. 18 (1): 183189.

Subhani, A., M. S. Awan, M. Anwar, U. Ali, N. I. Dar. 2010 Population status and distribution pattern of red jungle fowl (Gallus gallus murghi) in Deva Vatala National Park, Azad Jammu \& Kashmir, Pakistan: A Pioneer Study. Pakistan J. Zool. 42 (6): 701 - 706.

Sulandari, S. dan M.S.A. Zein. 2009. Analisis D-loop DNA mitokondria untuk memposisikan ayam hutan merah dalam domestikasi ayam di Indonesia. Media Peternakan. 32 (1): $31-39$.

Sulandari, S., M. S. A. Zein dan T. Sartika. 2008. Molecular characterization of indonesian indigenous chickens based on mitochondrial DNA Discontainersment (D)-loop Sequences. HAYATI Journal of Biosciences. 15 (4): 145 - 154.

Sutriyono, Setianto, J., Prakoso, H. 2016. Produksi dan populasi ayam hutan merah domestikasi di Kabupaten Bengkulu Utara dan skenario pengembangan populasi. Prosiding Seminar Nasional Masyarakat Biodiversitas Indonesia. Kerjasama Masyarakat Biodiversitas Indonesia, Institut Pertanian Bogor dan Universitas Sebelas Maret. Hotel Amaris Pakuan Bogor, 17 September 2016. 2 (2): $226-231$.

Sutriyono, J. Setianto, H.Prakoso, B. Zain. 2017. Conservation and utilization of red jungle fowl in the coastal areas of North Bengkulu. Proceeding International Seminar and Expo: Sustainable Utilization of Coastal Resources in Tropical Zone. University of Bengkulu. 19-20 October 2016. I: 370 - 376.

Widodo, J. Setianto dan Sutriyono. 2014. Performa produksi dan reproduksi ayam burgo di lingkungan terkontrol dalam upaya mendukung pelestarian biodiversitas. Naturalis. 3 (1): 90-98. 